\title{
Information and Arena. The Dual Function of the News Media for Political Elites
}

\begin{abstract}
How do individual politicians use the news media to reach their political goals? This study addresses the question by proposing an actor-centered, functional approach. We distinguish two essential functions (and sub-functions) the mass media have for political elites. The media are a source of information; politicians depend on it for pure information and they can profit from the momentum generated by media information. The media also are an arena elites need access to in order to promote themselves and their issues. These two functions offer certain politicians a structural advantage over others and, hence, are relevant for the power struggle among political elites. A systematic functional account allows to compare the role of the media across politicians and political systems.
\end{abstract}

Key words: political power, news media, press/politics, framing, strategic communication, functions of the mass media 


\section{Information and Arena. The Dual Function of the News Media for Political Actors}

\section{Introduction}

Social scientists have had a lot of attention for the news media's impact on public opinion (see for example for one of the earliest accounts: Lazarsfeld, Berelson, \& Gaudet, 1945). Until recently the relationship between news media and political elites received much less attention. Classic studies focusing on the power relationship between journalists and politicians were mainly interested in news making — and thus in the influence from politics on media — and less in policy making — the influence from media on politics (e.g. Blumler \& Gurevitch, 1981; Gans, 1979; Nimmo, 1964; Sigal, 1973; but see Cook, 1989). But during the last decade or so, the political consequences of the alleged intrusion of the news media in the political sphere gained considerable scholarly traction (e.g. Davis, 2010; Strömbäck, 2008; Wolfe, Jones, \& Baumgartner, 2013).

So far, the media and politics literature has mainly focused on how journalists and their news products have influenced the world of politics. The mediatization literature, for example, analyzes mainly how politics has adapted to the rules of the media logic. This work basically studies the media's intrusion into the political sphere and suggests that the media are politically influential (Strömbäck \& Esser, 2014). A different approach comes from scholars that study the impact of the news media on political priorities. Students of the political agenda contend that media coverage affects the priorities of presidents, parliaments and parties (e.g. AUTHORS, 2006). Although mediatization and political agenda-setting scholars differ in their account of how the media influence politics, they share the idea that political elites and institutions follow the media, and that the media thus possess at least some form of political power. When asked directly, many political elites agree that the media exert substantial power. A recent survey among politicians in nine European countries found that politicians 
perceive the media to have a large agenda-setting and 'career-controlling' power (Lengauer, Donges, \& Plasser, 2014). A host of other individual-level studies confirmed that political actors are strongly convinced of the media's power (Cohen, Tsfati, \& Sheafer, 2008; Maurer, 2011; AUTHORS, 2011). In sum, most theories and studies have focused on the relationship_better: the power struggle—between media and politics. This is what Gans (1979) labeled as the 'tango' between journalists and politicians, a metaphor that has been used repeatedly in the literature.

Apart from the fact that in most of this work the mass media have been posited 'against' politics-news media are implicitly considered to be a kind of 'foreign intruder' into politics - the relationship between media and politics has hardly been investigated from the perspective of political actors themselves. About fifteen years ago, Schudson (2002: 255) noticed in his overview of the media and politics literature that there were hardly studies that "look to the media from the viewpoint of politicians". Only more recently, a growing literature is putting the political process center stage by discussing the role of the mass media from the perspective of political actors. The PMP-model of Wolfsfeld (2011), for instance, holds that most things ultimately start in the political realm, then spill over to the media, and that, subsequently, political actors react to the media coverage (they themselves caused). In a similar way, Sellers' (2010) 'cycle of spin' starts with politicians willing to promote their message; these politicians take into account how their messages are covered in the media which, in turn, influences their political communication and even the policy debate. Also Entman's (2003) cascading model departs from the promotion of frames by political and bureaucratic elites but acknowledges the existence of an important feedback role of the news media.

Without denying the importance of the media, all these scholars start and end their analysis with the actions and goals of political actors. They adopt a political actor perspective 
and suggest that the media's impact mainly works via political actors that are (un)able to employ the media to further their goals (see also Hänggli \& Kriesi, 2010; Thesen, 2014). Such an alternative view of the media-politics relationship departing from the perspective of political elites is also gaining ground in recent studies on the mediatization of politics. For example, Esser and Strömbäck (2014: 227) observe a shift from a 'media-centric' to an 'actorcentric' perspective in mediatization research. More and more mediatization scholars seem to support the idea that the media matter not so much because political actors are forced to adapt to their logic, but rather because they (selectively) choose to adapt in so far as it fits their political purposes (see also Authors, 2014; Landerer, 2013; Marcinkowski \& Steiner, 2014). In other words, instead of pitching the mass media against political elites, the emerging actor perspective suggests that the media may have an impact on the struggle of power among different political elites. Although gaining ground, the political actor approach still lacks a systematic theoretical account that explicitly incorporates and compares the different functions the media perform for political elites.

Therefore, as a first step towards such a theory, our ambition here is to provide a functional framework of the meaning and role of the mass media for political elites in Western democracies. Our approach is 'functional' as it zooms in on the different functions the media have for politicians. A functional approach was quite common among the pioneers of mass communication research. For example, a long time ago, Harold Lasswell suggested several functions the media have for society at large (Lasswell, 1948; see also Graber, 2009). Building on his insights, other scholars studied the functions the mass media have for individual citizens, which became known as the 'uses and gratifications' approach (Katz, Blumler, \& Gurevitch, 1973a). These scholars typically generated a list of functions that different media might have in satisfying different sorts of citizen needs (e.g. Katz, Haas, \& Gurevitch, 1973b). This mass communication work strongly contributed to a shift in thinking 
Information and Arena. 5

about media effects from "what the media do to people" to "what the people do with media". We believe such a functional approach to be a fruitful way to study the role of media in politics; it directly addresses some of the shortcoming in previous studies on media and politics.

First, a functional approach focuses on why politicians use the mass media and provides systematic insights in the motives that underlie their interaction with the media. The importance of the media as a channel to reach the broader audience, for example, is more often suggested than actually examined. A functional approach can help us with understanding how and why some politicians use the media under certain circumstances while others do not, or are not able to. By focusing on the motives of politicians, a functional actor approach is well-suited for comparative research comparing different politicians in different systems. In fact, similar goals can be expected to motivate elected politicians in many systems but the constraints, resources and incentives provided by the political and media system may vary leading to systematic differences.

Second, a functional approach is in line with the widely accepted idea among political scientists that politicians are strategic actors with specific goals and ambitions that try to pursue those goals as good as they can (Strömbäck \& Van Aelst, 2013). It treats the media as a resource that can be used by politicians in the struggle over political power with other politicians. For instance, by attaining media access, anticipating media attention, or rhetorically using media coverage, politicians can improve their position in the political process (see also Kunelius \& Reunanen, 2012). In this way, a functional perspective examines whether and how media affect the balance of power amongst politicians, which probably is the main question political scientists deal with-namely: who gets what, when and how.

In short, we argue that a systematic analysis of the existing literature about media and politics through a functional lens leads to novel and coherent insights about the role of the 
media in the political process. We focus specifically on elected politicians in Western democracies as the units of analysis. This means we exclude other political actors such as social movement activists, leading civil servants, or non-elected authoritarian leaders. However, as we will briefly discuss at the end, we acknowledge the variety among political actors and reckon the functions of the mass media may play out differently for non-elite political actors in other positions.

Looking at the news media from a functional perspective, we argue the mass media essentially fulfill a dual function for political actors. Based on an extensive literature review, this article makes the distinction between the media as a source of information for political actors, and the media as an arena for political communication. Within the information function we further distinguish a passive from an active information sub-function. Politicians can learn from the media about the world out there, including the opinions of the public and other political actors. Yet, the fact that information encapsulated in media coverage is, by definition, also public creates a window of opportunity and politicians can profit from the momentum generated by the media information on a topic. The arena function as well has two sub-functions. On the one hand, politicians try to get access to the media arena to get attention and favorable coverage for them personally. On the other hand, politicians use the media arena to promote certain issues and their interpretation of these issues.

The study first discusses and conceptualizes the two central functions, information and arena, and their sub-functions. Next, we show how these two functions have been implicitly underlying much of the existing literature and how previous work can be structured according to the dual media function. We then move on to how our functional approach allows to investigate differences across actors and across political systems in how politicians use, and are dependent on the mass media. This then suggests a future research agenda. 


\section{The Two Functions of the Media for Political Elites}

First, the mass media form a source of information for political elites. Just like any citizen, individual politicians learn from the media about the world out there, even about the world of politics. The information the media offer is diverse and ranges from signaling the importance of societal problems to highlighting the positions other actors have taken towards those problems. What we call 'information' here can be a simple fact, like the actual inflation rate, as well as a government statement about the need to control inflation. So, the media provide politicians with information that they would otherwise not have or not pay attention to. But attention is scarce. Any topic can only draw a finite amount of time, space, money, resources, etc. Due to the architecture of the human mind and institutional limitations, the amount of attention is limited, since other topics are begging for attention as well. The assumption of attention scarcity applies to citizens (McCombs \& Shaw, 1972), to politicians and the political system as a whole (Simon, 1985; Jones \& Baumgartner, 2005), as well as to media coverage (Boydstun, 2013). The more attention the media devote to something-this is mostly a matter of the sheer prominence of a story in the news - the more the implicit message is conveyed that it is something important. In short, the media do not only make information available but also make it more salient, giving politicians an idea of what issues or persons are currently in the public eye. This first sub-function is purely informational; it relates to the passive role of politicians as mere consumers of information provided by the media.

Yet, politicians not only passively learn from the information provided by the mass media, they also actively use it in their daily work, this is the second information subfunction. If real world events or other political actors' plans for action or statements are covered by the news, this signal presents raw material for (other) political actors to factor in, or not, into their own actions, strategizing or positioning. In other words, information generates an opportunity for politicians to act and this is especially the case when that 
information is public, which is by definition the case with news media information. Information then becomes an instrument that can be used strategically by politicians to support their own goals or plans. This use can range from a backbencher using media coverage rhetorically in parliament to support a claim, over a party leader using the media momentum to put the party's issue higher on the governmental agenda, to a president using a massively covered accident to push his policy plans through parliament.

Second, the mass media as a whole form a political arena. Elites use this arena to reach out to the public. In many ways, the media arena is comparable to other arenas, such as the parliamentary arena. Competing actors make statements, undertake actions and try to get the upper hand. There are specific rules of conduct that apply to playing in the media arena, just like there are rules for how to act in the parliamentary arena or government arena. The notion that politics occurs in different political arenas is a classic idea in political science, in particular in the party literature (e.g. Muller, 2000; Strøm, Müller, \& Smith, 2010; Sjöblom, 1968; Strömbäck \& Van Aelst, 2013). Each arena has different inclusion and exclusion criteria and is ruled by different procedures. While party scholars typically devote little or no attention to the mass media as a political arena, Strömbäck (2007) suggests that political actors also act in a media arena, where they interact with journalists and editors and try to maximize positive and minimize negative publicity. Also Lawrence (2001) considers the media as an arena in which problems and events are identified and defined through the interaction of different actors. The media arena does not operate separately from the other arenas; it influences and is influenced by what happens in the other venues (Strömbäck \& Van Aelst, 2013; Kedrowksi, 1996; Sellers, 2010). Yet, for clarity's sake, we think it is fruitful to conceptualize the media arena as a distinct arena in its own right.

Politicians use the media arena in the first place to promote themselves, this is the first arena sub-function. At least those who hold an elected mandate, want to get publically known 
Information and Arena. 9

and therefore need to be into the news. Therefore, gaining media arena access is one of the key intermediary goals of most politicians. As many people (not only political elites) vie to be part of the news, the news media are very selective in letting politicians pass through their selection gates. News routines and news values make the media devote attention to some actors while neglecting others. In particular among lower ranked politicians, this leads to a fierce competition for the scarce space in the newspapers columns or TV shows.

Elites do not only require simple access to the media arena for self-promotion, they also aim to tell their own story in the media. This second arena sub-function could be labeled issue-promotion. Different actors have different stories to tell, or at least different versions of the story. They want to 'spin' an issue to their advantage, define it in a way that benefits them and the policies they favor. This implies that there is a 'framing competition' (Chong \& Druckman, 2013) between political actors over the definition of the news. Journalists have an active role in this process and prefer sources to play a predefined part in their story, the narrative of the events that the journalist is putting together.

By performing both functions at the same time, the role of information provider and of arena for promotion, the news media form a formidable resource for politicians affecting the power balance amongst political actors. The following section reviews the research literature from this bi-functional perspective and shows that the two functions (implicitly) underlie a large part of the extant work on media and politics.

\section{The Information Function}

Information is a crucial asset for politicians in their daily work (Baumgartner and Jones 2014). There are at least three types of information encapsulated in media coverage. First, media offer easy to digest information about prevailing problems in society. The ultimate job of politicians is to deal with societal problems (Green-Pedersen \& Mortensen, 2009) and the 
media are routinized and specialized detection instruments constantly digging up dirt and signaling problems across many policy sectors. In particular novel information produced by the media, for example through investigative journalism, has a high informative value and is frequently followed-up by political action (Cook et al., 1983; Protess et al., 1991). The attractiveness of the media information about problems lies in the fact that media signals are succinct and focused, which is according to Kingdon (1984) the type of information that is preferred by politicians. Cobb and Elder (1981: 392) claim that the media are useful for political actors to 'reduce the overwhelming information-processing tasks confronting policymakers'. Similarly, Kingdon (1984) showed how US members of Congress dealing with an oversupply of information turn to the media to know what really matters.

Second, from the media, politicians also learn about public opinion. They do so directly if media messages contain explicit information about what the public cares about and wants (e.g. media stories referring to opinion polls or containing popular exemplars). Politicians also learn indirectly about the public as they consider the news a proxy for the priorities and the positions held by voters (Herbst, 1998). Pritchard (1992: 105) calls this the 'media-assurrogate-for-public-opinion'-function of the media.

There is a third type of information politicians get out of the media: information about the agenda, the positions and the actions of other politicians. Decision-making processes often take place behind closed doors. Politicians thus regularly lack information about what is going on in politics itself, and what other actors are up to. Quite often, information about the policy process leaks out in the press (Hess, 1984; Reich, 2008). Additionally, the media simply cover politics - the statements politicians make, the plans they launch, the visits they undertake etc.- - and for a politician this may yield relevant information about what other (often more important) politicians (e.g. from the government) are up to (Linsky, 1986). In 
sum, politicians also learn from the media because its coverage contains (otherwise hidden) information about other political actors (Brown, 2010: 134; Sellers 2010: 8-9).

All this work on how politicians vie for information about problems, public opinion and what other actors are doing suggests that the media are a provider of sheer information for politicians. However, actual empirical work directly investigating the purely informational sub-function of the media for politicians is as good as entirely missing. Although studies have shown that most politicians are news junkies (e.g. AUTHOR et al., 2008; Davis, 2007), we know little about what they learn from it. There are hardly studies on the 'media dependency' of political actors. This is in sharp contrast to the attention that has been given to the information function of the media for ordinary citizens (e.g. the classic study about how the public depends on media information: Ball-Rokeach \& DeFleur, 1976). Studies are lacking as well that compare the role of the media as information provider with alternative sources of information such as interest groups, government agencies, ordinary citizens, party agencies etc.. Again, this is in contrast with the attention that is given in 'uses and gratification' research to alternative information sources (Katz et al., 1973b). The problem is that learning is a cognitive process and that scholars studying elites almost never get such close access to elites to actually study how these individual process information. There are plenty of studies, though, that show that elites act upon media information, but these studies tell us probably more about the second informational sub-function, namely how media information creates an opportunity for strategic political actors.

Indeed, the empirical proof of the fact that politicians actively use the information provided by the media is substantial. There is a growing body of work about elites' attentional behavior; media signals about issues do get picked up by elites. Observing the media-reactive behavior of political actors, this literature strongly suggests that politicians derive information from media coverage and that they profit from the momentum generated by the information to 
use it in their work. When the media address an issue, politics follows suit and politicians increasingly start to talk about it (Eissler, Russell, \& Jones, 2014; AUTHORS, 2006). This literature, faring under the header of 'political agenda-setting and the media', has showed that the media affect the political agenda in many countries, both in majoritarian and in proportional democracies (e.g. Bonafont \& Baumgartner, 2013; Edwards \& Wood, 1999; Soroka, 2002; Van Noije, Oegema, \& Kleinnijenhuis, 2008; Walgrave, Soroka, \& Nuytemans, 2008). Research that does not analyze elites' behavior, but instead directly asks them where they get their information for action from, confirms the informational function of the media for political elites. For instance, a study among MPs in fifteen European countries showed that, according to their own saying, the media is one of the most frequently used ‘sources of inspiration' for parliamentary initiatives (AUTHORS, 2014).

Whereas there is ample proof of the fact that politicians react to news coverage and actively engage with issue information provided by the media, most of this research concluded that politicians are by no means naïve or ordinary news consumers (Davis, 2007). They are rational actors that strategically use the media. Because typical media messages are better suited to nurture the opposition's goal, destabilizing and embarrassing the government, opposition members more often profit from the window of opportunity provided by media information than members of government parties (Green-Pedersen \& Stubager, 2010). Also, parties react more to media when the media cover issues that they 'own' than when they cover other issues (Vliegenthart \& Walgrave, 2011a, 2011b). Parties are advantaged regarding the issues they are considered to be the most competent on (Budge \& Farlie, 1983; Petrocik, 1996), which is why they strategically embrace the selective media information that plays to their advantage. Several studies have shown that political actors do not automatically react to media information as it becomes more salient, but mainly, or only, when this information fits their already existing issue agenda. So, the news not only provides useful information about 
topics and events, but offers a window of opportunity for some political actors to highlight their existing issue priorities (Elmelund-Præstekær \& Wien, 2008; Kingdon, 1984; Yanovitsky, 2002).

Not only the saliency of the information on issues encapsulated in the news creates a window of opportunity for politicians. News media also define and interpret issues. Older work by Kingdon (1984) on US congressmen found that opinionated and framed media information, media signals of which the political meaning has been defined, often has a higher informative value for political elites than bare-bone factual information. Facts that have been predigested require less effort for politicians to make up their mind and adopt a position. So, media frames increase or decrease the relevance of the underlying facts for elites. Recently, scholars have started to integrate elements of framing into classic political agenda-setting studies. Thesen's work on Denmark is exemplary in this respect. He found that opposition parties ask more parliamentary questions about those issues that have been in the news negatively. And, they are especially active on issues when the triggering media story contains a responsibility frame blaming the government for the undesirable state of affairs (Thesen, 2013, 2014). Van der Pas (2013) found that politicians in the Netherlands and Sweden mainly respond to media coverage when the media frames are closer to their own definition of the issue. This emphasizes, again, the strategic nature of political reactions to media coveragepolitical actors employ media frames when they are congruent with their own position. As a consequence, media frames do not get picked up equally by political actors across the political spectrum. For instance, Vliegenthart \& Roggeband showed that media coverage of immigration in the Netherlands after 9/11 was overwhelmingly driven by a so-called 'Islamas-a-threat'-frame. This correlated with the discourse used by right-wing parties in parliament but most other parties kept on using their own frames and rejected the dominant media frame (Roggeband \& Vliegenthart, 2007; Vliegenthart \& Roggeband, 2007). 


\section{The Arena Function}

Politicians get 'pure' information from the media and, at the same time, media information, through its salience and framing, creates an opportunity to act. But for politicians to reach out to the public, they need to become the object of coverage themselves. Being selected into the news, though, does not mean that you get what you want. This section distinguishes the mere acquisition of personal media attention for political actors (self-promotion) by accessing the media arena from being allowed to also get one's message discussed (issue promotion) in that arena.

For ordinary citizens, the news media are the dominant way to learn about most actors, issues and policies (Bennett \& Entman, 2001). Mediation by the media is a precondition for the mediatization of politics (Shehata \& Strömbäck, 2014). Since politicians in democracies need public support and since the media provide the most important channel to gain such support, political actors have little choice but to play the media game. Besides a direct electoral connection, presence in the media arena can also have indirect electoral effects. Parties may put candidates that successfully enter and perform in the media arena higher on the ballot list (Davis, 2010; AUTHOR, 2008) or mediatized candidates may attract more funding from sponsors (e.g. Heldman, Carroll, \& Olson, 2005). The importance of entering and performing in the media arena goes well beyond elections. Kunelius and Reunanen (2012), for instance, show with a survey among Finnish elites that media attention can also strengthen one's position in the policy process (see also Cook, 2005: 143).

Ample studies have shown that the media arena follows standard practices and routines (Sparrow, 2006) that are a consequence of the function and aim of the media in modern society. The arena is ruled by news values (Galtung \& Ruge, 1965; O’Neill \& Harcup, 2009) and produces news in specific formats (Altheide \& Snow, 1979). Thus, politicians' media 
arena inclusion or exclusion is not random, but obeys a number of well-known criteria guiding news makers in their decisions regarding who is in and who is out. In other words, the news media form an institution characterized by recurring patterns of behavior and collectively shared beliefs of what is news (Cook, 2005). Journalists' decisions to incorporate events or actors in the news and to give them the space to present their points of view are steered by particular media routines and standards of newsworthiness rather than by what political actors consider to be relevant (Wolfsfeld, 2011: 72; Cook, 2005: 63). To enter the media arena and to successfully get their version of the facts into the news, politicians need to learn and incorporate these media rules (Davis, 2007; Strömbäck \& Esser, 2014). The media arena is not a level playing-ground and in that respect not so different from the other arenas politicians operate in. Media routines advantage particular politicians, just like the rules in the parliamentary arena favor certain actors (e.g. the priority government initiatives get in most parliaments). Note that for politicians willing to enter the mass media, their competitors are not journalists, but rather other politicians (even of their own party) who vie for a place in the media spotlights as well. Journalists and editors impose the rules of the media game to the players, they can be considered as the referees that assess whether the actors play to the rules, but the real competitors are the other politicians. In sum, politicians have a strong interest in entering the media arena to communicate to the public and therefore they have to incorporate the media rules.

A sizeable empirical literature supports the idea that getting access to the media arena is highly predictable. It is common knowledge that media attention is skewed in favor of actors with formal political power like presidents, prime ministers, party leaders, etc. (Bennett, 1996; Schönbach, De Ridder, \& Lauf, 2001). Also for common politicians, for which access may even be more crucial, relative small status differences-e.g. for a parliamentarian: being a committee chair or not—are strong predictors of media exposure (Cook, 1986; Sellers \& 
Schaffner, 2007; Tresch, 2009). Some studies suggest that working hard in parliament leads to more coverage (Bowler, 2010; Midtbø, 2011), while others found no such diligence effect (Fogarty, 2008; Tsfati, Markowitz Elfassi \& Waismel-Manor, 2010). Scholars have also looked at non-institutional aspects to explain the media attention politicians get like their communication skills (Sheafer 2001) or physical attractiveness (Rosar, Klein, \& Beckers, 2008; Waismel-Manor \& Tsfati, 2011). The news media prefer charismatic, communicative and attractive politicians but, at the same time, highly value the institutional status of elites and rather strengthen instead of challenge the politically defined hierarchy (Wolfsfeld, 2011). So, the rules of media access are to some extent specific to the media logic but they are also strongly related to essentially political and often institutional features of politicians (for an overview see Vos, 2014).

Frequent media access may be a privilege of the powerful and a necessary condition for self-promotion, it does not automatically imply that the attention is positive. The favorability of news coverage can be crucial in how citizens' perceive a political actor, in particular in election times (e.g. Druckman \& Parkin, 2005; Shaw, 1999). A lot depends on whether the covered actor gets the chance to promote the issue or frame he or she would like to get across to the public. In other words, mere media access does not imply that one is able to spin the story to one's own advantage. A telling example is that of British PM Tony Blair, for a decade the most prominent politician in the British press, who, when he left office, expressed deep personal dissatisfaction with the role of the media in politics (Seaton, 2007). Paradoxically, Blair and his New Labour governments—sometimes called 'The Sultans of Spin'-were frequently mentioned as a prime example of how politicians (ab)used the media to their advantage (e.g. Jones, 1995, 1999; Kuhn, 2002). The US literature too abounds with proof of how those in power, and the US President in particular, have successfully been able to broadcast their messages in the news. The combination of a strong institutional position, 
professional public relations techniques, and specialists in news management, makes the US government an exceptionally influential communicator often succeeding in getting its message out in the media (Kernell, 2007; Lieber \& Golan, 2011; Manheim, 1998). For instance, several studies showed how, in the aftermath of $9 / 11$, the Bush administration was successful in making its frame on the War on Terror prevail in the media (Bennett, Lawrence, \& Livingston, 2007; Domke, Graham, Coe, Lockett John, \& Coopman, 2006; Reese \& Lewis, 2009). According to Entman's (2003) cascading activation model, the frame was initiated by the President and was taken over by other elites, amply broadcasted by the news media and, ultimately, adopted by the public. In line with Bennett's indexing theory (1990), the government-sponsored War on Terror frame was initially left unchallenged by journalists, but simply covered time and again. As time went by, the media began to devote more attention to frames sponsored by alternative sources and the government spin regarding the War on Terror became less prevalent in the media (see also Glazier \& Boydstun, 2012).

The (temporally) dominant position of the US government's message after 9/11 may not seem uncommon for scholars of US policy and media, but it is rather exceptional in many other countries. Most governments have less political communication resources and, more importantly, their messages are more often challenged by multiple actors. For instance, in European multi-party systems most political debates involve multiple political parties that each promote their definition and interpretation of the issue at stake (Slothuus \& De Vreese, 2010; Helbling, Hoeglinger, \& Wüest, 2010). Even in the US, when looking at policy domains beyond foreign policy, there is a good deal of elite competition over messages in the news (Schaffner \& Sellers, 2010). More often than not, frames are contested by counterframes (Chong \& Druckman, 2013). In recent years, there is growing scholarly interest for these 'framing contests' among political actors in the news (see for example: Hänggli \& Kriesi, 2010, 2012). 
The fact that the media form an indispensable arena for politicians to show themselves to the public and to highlight their version of reality, does not mean that all battles over the meaning of issues are fought out in the media arena. Sellers (2000) showed that in legislative debates in the US, the majority party mostly prefers to keep the debate inside congress, while the minority party has more to gain by expanding the debate to the media arena. In particular when its frame is more in line with public opinion, the opposition party can win a legislative battle over a party in government by going public. Political actors in a weaker institutional (minority) position need media access more than those having institutional political power. Yet, at the same time, the media prefer to give the stage to influential, executive actors and successfully making claims in the media arena is more difficult for opposition parties (Shehata, 2010). As a consequence, the news media largely broadcast the messages of the most powerful players in particular (Hänggli, 2012).

This section distinguished two arena sub-functions: getting personal access to the media arena and getting your message across in that arena. Of course, both phenomena are connected. What a politician publicly states, and the way the message is framed, has a profound effect on whether he or she will make it into the news. One of elites' access strategies, for example, is making a controversial statement. For backbenchers or newcomers, provocative statements are even more needed to be selected into the news. A recent study in the Netherlands shows how populist politicians like Pim Fortuyn and Geert Wilders were able to attract enduring media attention by consistently using blunt and often insulting language (Bos \& Brants, 2014).

\section{Differentiating and Integrating Information and Arena}

We argued so far that the media exert a dual function for political actors. They are providers of information that can be passively consumed or actively used by politicians. And, they form 
an arena actors need access to in order to promote themselves or their issues. We reviewed the literature on media and politics and showed these functions and sub-functions to implicitly underlie a good many of the extant studies on media and politics. Making these implicit functional arguments explicit and turning them into a systematic functional framework is the primary contribution of our study.

Yet, we think the usefulness of the functional framework for studying the relationship between media and politics could be further demonstrated. A functional framework not only allows to conveniently classify existing studies and create some order in the chaos. It also highlights the lacunae in the present literature that future work may want to focus upon. Concretely, in this section, we first show that differentiating political actors and functions allows for a better reading of what existing work actually taught us about the media's interaction with politics. Second, we argue that most progress can be made by research integrating both functions and looking into how they interact.

\section{Differentiating Functions and Politicians}

The information and arena functions are more or less central to the goals and functioning of different types of politicians. Talking about the functions of the media for the politicians may not be a good idea, though. Our literature review showed there to be strong variations in the potential usefulness of the information and arena resources the media offer to different types of politicians. In other words, in the power struggle among political elites, the two functions play to the (dis)advantage of different political elites. We elaborate on this further by distinguishing three levels (micro, meso and macro) on which we can differentiate politicians from one another.

On the micro-level, it is well-established that politicians with more formal power have a closer relationship with the media compared to politicians with lower political status. Power 
leads to a clear advantage in the media arena with more access leading to more chances to promote oneself and one's pet issues. Yet, in terms of the usefulness of the media's information for political actors other features of individual politicians seem to matter. Especially for generalist politicians and politicians who engage in partisan battle, for example, the daily menu of negative and conflictual news offers plenty of material they can work with (Sevenans, Walgrave, \& Vos, 2015). So, distinct individual features affect arena access and information usefulness. While it is probably true that some individual politicians are structurally advantaged or disadvantaged by the mass media, it may well be the same politicians who experience an advantage in one function while at the same suffering from a disadvantage in the other function.

The same applies to the meso-level. Here it is the government-opposition divide that counts. The existing studies suggest that differences between government and opposition politicians can be adequately tied to the media's two functions, information and arena. While government actors have a clear structural advantage when it comes to the media as an arena, opposition actors are more served by the media as a source of information. With regards to the informational function, mass media coverage is more directly applicable and useful—and thus more advantageous-for opposition members. The opposition can use media coverage, in particular negative and conflictual stories, to challenge a minister's plans or attribute responsibility for things going wrong (e.g. Thesen, 2012, 2013). Regarding the arena function, in contrast, the executive branch has a clear advantage and sidelines the opposition. In particular outside election times, powerful actors from the executive get more access to the media arena and they receive more space to promote themselves and their issues (GreenPedersen, Mortensen, \& Thesen, 2015; van Dalen, 2011).

At the macro-level, system characteristics may influence the role the media plays for different political elites. For instance, a political system in which power is shared among more 
actors may create a stronger competition for media access compared to systems with a limited number of political actors (Van Dalen \& Van Aelst, 2014). At the same time, in a more fragmented system with less information asymmetry between government and opposition, media information may also be relevant for governmental actors and not just for the opposition. Characteristics of the media system as well, such as the degree of political parallelism (Hallin \& Mancini, 2004), may influence how different politicians are (un)able to use the media's information and arena functions to reach their political goals. A recent study, for example, showed that Spanish parliamentarians mainly use the newspaper they are ideologically close to while Dutch MPs do not distinguish between ideologically close or distant newspapers as a source of information (Vliegenthart \& Mena Montes, 2014). In contrast with research on micro- and meso-level factors, empirical research about the effect of system characteristics on the information and arena role of the media still is largely absent.

In sum, it does not seem likely that some politicians are wholly advantaged and can invariably use the media to their own benefit, nor does it seem to be true that other politicians are fully deprived of employing the media for their own profit. Further research distinguishing kinds of politicians while examining how and why they differently employ the media's information as well as arena function is likely to contribute to what we know about media and politics.

\section{Integrating the Information and Arena Function}

Apart from differentiating both functions and assessing how they play to the advantage of different politicians, a second rare but promising field of research does just the opposite: integrating both functions. While analytically distinct, in reality both functions are connected. Yet, we know little about how the information and arena functions of the media relate to each other. For example: To what extend does reacting to media information increase arena access? 
Media access is highly predictable with a small group of elite politicians dominating news coverage. The powerful initiate news stories while 'ordinary' politicians are forced to react to what is already in the news in order to get access to the media arena (Van Santen, Van Aelst, \& Helfer, 2015; AUTHORS, 2014). Especially when the salience of a topic in the media strongly increases (irrespective of what political actors are doing) this opens up possibilities for a broader range of politicians to make it into the news (Kepplinger \& Habermeier, 1995). A recent longitudinal Danish study showed, for instance, that when issue salience increases the media's strong focus on government actors withers and opposition parties receive more coverage (Green-Pedersen et al., 2015: 11). In particular when an issue explodes on the news agenda and a media storm breaks, the news selection criteria temporarily change: journalists seek to satisfy the public's need for more news about the triggering event or story (Boydstun, Hardy, \& Walgrave, 2014). Such changes in the salience of certain issues do not suddenly make the media arena a level playing field, access remains selective, but backbenchers may become (temporarily) more newsworthy and gain access more easily. Wolfsfeld and Sheafer (2006) investigated how different types of 'news waves' provide media access opportunities to Members of the Knesset with different characteristics. Charismatic communication skills, they show, are important to get media access in so-called 'open waves', while thematic expertise is more relevant in more restricted waves.

On many other potentially important questions regarding how the arena and information functions of the mass media relate to each other, we do not even have the beginning of an answer. For example, to what extent does the media arena access of politicians form useful information for other politicians? We expect politicians to learn more from media information about problems and public opinion than about the political game itself, but we hardly have a clue of how pervasive the information function of the media really is. In sum, it is in investigating the interaction between both media functions that most progress is to be made. 


\section{Conclusion}

While the literature on media and politics is booming there is growing consensus that the media plays an important role in politics. However, little systematic attention has been given to why and how politicians use the media. Therefore, we took stock of the existing literature from the perspective of strategic political actors that use the mass media to reach their political goals and realize their ambitions. A functional actor-perspective, we argued, helps refocusing attention to the struggle for power between political elites and to go beyond the sterile debate about whether media or politics prevails. Media matter for political power as the information encapsulated in media messages is more relevant for some politicians and as gaining access to the media arena is unequally divided across politicians.

The media has two core political functions, and these functions implicitly underlie most of the work on media and politics. The information function has a passive and an active component. Media can serve as a source of pure information, but that information can also be an instrument that is used by politicians. The arena function refers to the mass media as a unique platform to attract public attention. Politicians need to access this arena to get attention for themselves but also to promote their issues. We are not the first to make this distinction but we are novel in making it explicit and in showing that most work on media and politics can clearly be categorized as investigating one of these two functions or sub-functions. Our functional account of media and politics also clarifies why previous work came to different conclusions. Depending on the function one focuses upon or the actor one deals with, the dependency of politicians on the media may vary dramatically. Some political elites profit more from the media information and/or the media arena than others.

Additionally, our functional account marks significant lacuna in our knowledge about media and politics. Most progress in the field can probably be made by looking into 
comparative differences across political and media systems in how the media are used by political actors. The relevance of the arena and information functions of the mass media differ across systems and across position holders in those systems. For example, the US president does not depend a lot on the media for his information and he can get access to the media any time. A backbencher opposition MP in a fragmented European country, gets a good deal more of his or her information from the mass media and has a hard time getting into the media. Differences between these two actors-both are called 'elites' - in their dealings with the media are large and the field could profit from such a systematic comparative approach.

We are aware that our functional approach may implicitly suggest that the media are passive actors and that the action only occurs on the side of politics. This is not the case, obviously. The media are active gatekeepers deliberately opening their gates for some politicians more than for others and/or consciously favoring some politicians' issue promotion above others. Our point is precisely that politicians can use these systemic biases or skews in media information and, by adapting their behavior accordingly, can play the media arena. In doing the latter, political actors can beat a political opponent in the media arena but they cannot 'beat' the arena as such. Our approach is largely in line with Cook (2005) who holds that the media are a social institution that influences how things are done in politics. We acknowledge that sometimes this systematic influence of mass media coverage is complemented by an even more active role when certain media outlets become actors with their own political goals. In countries like the US, where partisan outlets are on the rise (Groeling, 2013), and in the UK, where partisan outlets have been a constant feature of the media system (Deacon \& Wring, 2015), the media's influence may go beyond the double function we conceptualized here. Yet, we believe that, rather than partisan or ideological, the main political role of the media is systemic and structural and thus best studied from the 
perspective of the political actors who are confronted with it and try to use it to their advantage.

In this article we focused on what drives politicians to use the mass media in their work. Our functional approach might be applied more broadly than we did here. For example, while we mainly drew on studies dealing with the traditional print and audio-visual news media, it would be relevant to apply it to the entertainment media or to the rapid growing field of social media. Our approach also opens up perspectives to study other political actors than the ones we implicitly kept in mind here: elected individual politicians. So-called political outsiders such as social movement leaders, interest group activists or lobbyists, or insiders such as leading civil servants and bureaucrats employ the information and arena function of the media as well, yet differently. For non-elected actors there may be less balance in the double role the media play. For example, social movements mainly want to get into the media arena and they probably depend less on the media as a source of information, because as specialists on their topic or theme, they have plenty of expert information about the things they work on. Other actors such as bureaucrats might be less interested in the arena function, because they do not need to present themselves to the public, but may still find certain types of information presented in the media important for their work. What makes elected politicians unique is that they need the media for information and as an arena at the same time. It is this double bind that turns media into a formidable resource for politicians. 


\section{References}

Altheide, D., \& Snow, R. P. (1979). Media logic. Beverly Hills: Sage.

Ball-Rokeach, S. J., \& DeFleur, M. L. (1976). A dependency model of mass-media effects. Communication Research, 1, 3-21.

Baumgartner, F., \& Jones, B. (2014). The Politics of Information. Problem Definition and the Course of Public Policy in America. Chicago: Chicago University Press.

Bennett, L. (1990). Toward a theory of press-state relations. Journal of Communication, 2(40), 103125.

Bennett, L. (1996). News. The politics of illusion (3rd ed.). New York: Longman Publishers USA.

Bennett, L., \& Entman, R. (2001). Mediated Politics: Communication in the Future of Democracy. Cambridge: Cambridge University Press.

Bennett, L., Lawrence, R., \& Livingston, S. (2007). When the Press Fails. Political power and the news media from Iraq to Katrina. Chicago: University of Chicago Press.

Blumler, J. G., \& Gurevitch, M. (1981). Politicians and the press: An essay on role relationships. In D. D. Nimmo \& K. R. Sanders (Eds.), Handbook of Political Communication (pp. 467-493). Beverly Hills, CA: Sage.

Bonafont, L. C., \& Baumgartner, F. R. (2013). Newspaper attention and policy activities in Spain. Journal of Public Policy, 33(01), 65-88. doi: doi:10.1017/S0143814X12000219

Bos, L., \& Brants, K. (2014). Populist rhetoric in politics and media: A longitudinal study of the Netherlands. European Journal of Communication. doi: 10.1177/0267323114545709

Bowler, S. (2010). Private Members' Bills in the UK Parliament: Is There an 'Electoral Connection'? The Journal of Legislative Studies, 16(4), 476-494. doi: 10.1080/13572334.2010.519457

Boydstun, A. (2013). Patterns in the News: How Policy Issues Make the Front Page.

Boydstun, A. E., Hardy, A., \& Walgrave, S. (2014). Two Faces of Media Attention: Media Storm Versus Non-Storm Coverage. Political communication, 31(4), 509-531.

Brown, R. (2010). The media and the policy process. A policy centric approach. . In K. Voltmer \& S. Koch-Baumgarten (Eds.), Public policy and mass media : the interplay of mass communication and political decision making (pp. 127-142). London: Routledge.

Budge, I., \& Farlie, D. (1983). Explaining and Predicting Elections. London: Allen \& Urwin.

Chong, D., \& Druckman, J. N. (2013). Counterframing effects. The Journal of Politics, 75(01), 1-16.

Cobb, R. W., \& Elder, C. D. (1981). Communication and public policy. In D. S. Nimmo \& K. R. (Eds.), Handbook of Political Communication (pp. 391-416). Beverly Hills: Sage.

Cohen, J., Tsfati, Y., \& Sheafer, T. (2008). The influence of presumed media influence in politics. Public Opinion Quarterly, 72, 331-344.

Cook, F. L., Tyler, T. R., Goetz, E. G., Gordon, M. T., Protess, D., Leff, D. R., \& Molotch, H. L. (1983). Media and Agenda Setting: Effects on the Public, Interest Group Leaders, Policy Makers, and Policy. Public Opinion Quarterly, 47, 16-35.

Cook, T. E. (1986). House Members as Newsmakers: The Effects of Televising Congress. Legislative Studies Quarterly, 11(2), 203-226. doi: 10.2307/439876

Cook, T. E. (1989). Making laws \& making news. Media strategies in the US house of representatives. Washington DC: The Brookings Institution.

Cook, T. E. (2005). Governing with the news: The news media as a political institution (2nd edition). Chicago: University of Chicago Press.

Davis, A. (2007). Investigating Journalist Influences on Political Issue Agendas at Westminster. Political communication, 24(2), 181-199.

Davis, A. (2010). Political Communication and social theory. London: Routledge.

Deacon, D., \& Wring, D. (2015). Still live in the old attack dogs: The press. In P. Cowley \& D. Kavanagh (Eds.), The British General Election of 2015 (pp. 302-335): Palgrave Macmillan.

Domke, D., Graham, E. S., Coe, K., Lockett John, S., \& Coopman, T. (2006). Going Public as Political Strategy: The Bush Administration, an Echoing Press, and Passage of the Patriot Act. Political communication, 23(3), 291-312. doi: 10.1080/10584600600808844 
Druckman, J. N., \& Parkin, M. (2005). The Impact of Media Bias: How Editorial Slant Affects Voters. Journal of Politics, 67(4), 1030-1049. doi: 10.1111/j.1468-2508.2005.00349.x

Edwards, G. C., \& Wood, D. (1999). Who influences whom? The President, Congress and the Media. American Political Science Review, 93(2), 327-344.

Eissler, R., Russell, A., \& Jones, B. D. (2014). New Avenues for the Study of Agenda Setting. Policy Studies Journal, 42, S71-S86. doi: 10.1111/psj.12048

Elmelund-Præstekær, C., \& Wien, C. (2008). What's the Fuss About? The Interplay of Media Hypes and Politics. The International Journal of Press/Politics, 13(3), 247-266.

Entman, R. M. (2003). Cascading activation: contesting the White House's frame after 9/11. Political communication, 20, 415-432.

Galtung, J., \& Ruge, M. (1965). The structure of foreign news. Journal of Peace Research(2), 64-91.

Gans, H. J. (1979). Deciding what's news: A study of CBS Evening News, NBC Nightly News. New York: Pantheon.

Glazier, R. A., \& Boydstun, A. E. (2012). The President, the Press, and the War: A Tale of Two Framing Agendas. Political communication, 29(4), 428-446. doi: 10.1080/10584609.2012.721870

Graber, D. A. (2009). Mass media and American politics: Sage.

Green-Pedersen, C., \& Mortensen, P. (2009). Who sets the agenda and who responds to it in the Danish parliament? A new model of issue competition and agenda-setting. European Journal of Political Research, 49(2), 257-280.

Green-Pedersen, C., Mortensen, P. B., \& Thesen, G. (2015). The Incumbency Bonus Revisited: Causes and Consequences of Media Dominance. British Journal of Political Science, 1-18.

Green-Pedersen, C., \& Stubager, R. (2010). The Political Conditionality of Mass Media Influence. When do Parties follow Mass Media Attention. British Journal of Political Science, 1-15. doi: $10.1017 /$ S0007123410000037

Groeling, T. (2013). Media Bias by the Numbers: Challenges and Opportunities in the Empirical Study of Partisan News. Political Science, 16(1), 129.

Hallin, D., \& Mancini, P. (2004). Comparing Media Systems. Three model of Media and Politics. New York: Cambridge University Press.

Hänggli, R. (2012). Key Factors in Frame Building: How Strategic Political Actors Shape News Media Coverage. American Behavioral Scientist, 56(3), 300-317. doi: 10.1177/0002764211426327

Hänggli, R., \& Kriesi, H. (2010). Political Framing Strategies and Their Impact on Media Framing in a Swiss Direct-Democratic Campaign. Political communication, 27(2), 141-157. doi: $10.1080 / 10584600903501484$

Hänggli, R., \& Kriesi, H. (2012). Frame Construction and Frame Promotion (Strategic Framing Choices). American Behavioral Scientist, 56(3), 260-278. doi: 10.1177/0002764211426325

Helbling, M., Hoeglinger, D., \& Wüest, B. (2010). How political parties frame European integration. European Journal of Political Research, 49(4), 495-521. doi: 10.1111/j.14756765.2009.01908.x

Heldman, C., Carroll, S. J., \& Olson, S. (2005). "She Brought Only A Skirt": Print media coverage of Elizabeth dole's bid for the Republican presidential nomination. Political communication, 22(3), 315-335.

Herbst, S. (1998). Reading public opinion: How political actors view the democratic process. Chicago: University of Chicago Press.

Hess, S. (1984). The Government/Press Connection. Washington, DC: Brookings Institution.

Jones, B., \& Baumgartner, F. (2005). The Politics of Attention. How Government Prioritizes Attention. Chicago: University of Chicago Press.

Jones, N. (1995). Soundbites and spin doctors. How politicians manipulate the media and vice versa. London: Cassell.

Jones, N. (1999). Sultans of spin: Gollancz London.

Katz, E., Blumler, J. G., \& Gurevitch, M. (1973a). Uses and Gratifications Research. The Public Opinion Quarterly, 37(4), 509-523. 
Katz, E., Haas, H., \& Gurevitch, M. (1973b). On the use of the mass media for important things. American sociological review, 164-181.

Kedrowksi, K. (1996). Media entrepreneurs and the media enterprise in the U.S. Congress. Cresskill, N.J.: Hampton Press

Kepplinger, H. M., \& Habermeier, J. (1995). The Impact of Key Events on the Presentation of Reality. European Journal of Communication, 10(3), 371-390.

Kernell, S. (2007). Going public. New strategies of presidential leadership (4th ed.). Washington, DC: CQ Press.

Kingdon, J. W. (1984). Agendas, alternatives and public policies: Harper Collins.

Kuhn, R. (2002). The first Blair government and political journalism. In E. Neveu \& R. Kuhn (Eds.), Political Journalism: New Challenges, New Practices (pp. 47-68): Routledge.

Kunelius, R., \& Reunanen, E. (2012). Media in Political Power: A Parsonian View on the Differentiated Mediatization of Finnish Decision Makers. The International Journal of Press/Politics, 17, 6876. doi: $10.1177 / 1940161211424207$

Landerer, N. (2013). Rethinking the Logics: A Conceptual Framework for the Mediatization of Politics. Communication Theory, 23(3), 239-258. doi: 10.1111/comt.12013

Lasswell, H. D. (1948). The structure and function of communication in society. The communication of ideas, 37, 215-228.

Lawrence, R. G. (2001). Defining events: Problem definition in the media arena. In R. Hart \& B. H. Sparrow (Eds.), Politics, discourse, and American society: New agendas (pp. 91-110). Maryland: Rowman \& Littlefield.

Lengauer, G., Donges, P., \& Plasser, F. (2014). Media power in politics. In B. Pfetsch (Ed.), Political Communication Cultures in Europe. Attitudes of political actors and journalists in nine countries (pp. 171-195). Basingstoke: Palgrave.

Lieber, P., \& Golan, G. (2011). Political Public Relations, News Management, and Agenda Indexing. In J. Stromback \& S. Kiousis (Eds.), Political Public Relations. Principles and Applications (pp. 5474): Taylor and Francis.

Linsky, M. (1986). Impact : how the press affects federal policymaking. New York: W.W. Norton.

Manheim, J. (1998). The News shapers: Strategic communication as a Third force in News making'in D. Graber, D. McQuali and Norris (Eds.) The Politics of News and the News of Politics: Washington, DC: Congressional Quarterly Press.

Marcinkowski, F., \& Steiner, A. (2014). Mediatization and Political Autonomy: A Systems Approach. In J. Strömbäck \& F. Esser (Eds.), Mediatization of Politics: Understanding the Transformation of Western Democracies (pp. 74-89). Basingstoke: Palgrave Macmillan.

Maurer, P. (2011). Explaining perceived media influence in politics. An analysis of the interplay of context and attitudes in four European democracies. Publizistik, DOI 10.1007/s11616-1101010104-11613.

McCombs, M. E., \& Shaw, D. (1972). The agenda-setting function of the mass media. Public Opinion Quarterly, 69(4), 813-824. doi: 10.1086/267990

Midtb $\varnothing$, T. (2011). Explaining Media Attention for Norwegian MPs: A New Modelling Approach. Scandinavian Political Studies, 34(3), 226-249. doi: 10.1111/j.1467-9477.2011.00270.x

Muller, W. C. (2000). Political parties in parliamentary democracies: Making delegation and accountability work. European Journal of Political Research, 37(3), 309-333. doi: 10.1111/1475-6765.00515

Nimmo, D. (1964). Newsgathering in Washington. A study in political communication. New York: Atherton Press.

O'Neill, D., \& Harcup, T. (2009). News values and selectivity. The handbook of journalism studies, 161174.

Petrocik, J. R. (1996). Issue ownership in presidential elections, with a 1980 case study. American Journal of Political Science, 40(3), 825-850.

Pritchard, D. (1992). The news media and public policy agendas. In D. Kennamer (Ed.), Public Opinion, The Press and Public Policy (pp. 103-112). Westport, CT: Praeger. 
Protess, D., Cook, F. L., Doppelt, J. C., Ettema, J. S., Gordon, M. T., Leff, D. R., \& Miller, P. (1991). The journalism of outrage: investigate reporting and agenda building in America. New York: Guilford Press.

Reese, S. D., \& Lewis, S. C. (2009). Framing the War on Terror: The internalization of policy in the US press. Journalism, 10(6), 777-797. doi: 10.1177/1464884909344480

Reich, Z. (2008). The anatomy of leaks. Tracing the path of unauthorized disclosure in the Israeli press. Journalism, 9, 555-581.

Roggeband, C., \& Vliegenthart, R. (2007). Divergent framing: The public debate on migration in the Dutch parliament and media, 1995-2004. West European Politics, 30(3), 524-548. doi: $10.1080 / 01402380701276352$

Rosar, U., Klein, M., \& Beckers, T. (2008). The frog pond beauty contest: Physical attractiveness and electoral success of the constituency candidates at the North Rhine-Westphalia state election of 2005. European Journal of Political Research, 47(1), 64-79.

Schaffner, B. F., \& Sellers, P. J. (2010). Winning with words: the origins and impact of political framing: Routledge.

Schönbach, K., De Ridder, J., \& Lauf, E. (2001). Politicians on TV News: Getting attention in Dutch and German election campaigns. European Journal of Political Research, 39(4), 519-531. doi: 10.1111/1475-6765.00586

Schudson, M. (2002). The News Media as Political Institutions. Annual Review of Political Science, 5(1), 249-269. doi: doi:10.1146/annurev.polisci.5.111201.115816

Seaton, J. (2007). Feral Beasts: An Introduction to Tony Blair's Reuters Speech on the Media. The Political Quarterly, 78(4), 471-475.

Sellers, P. (2010). Cycles of Spin. Strategic communication in the US congress. New York: Cambridge University Press.

Sellers, P. J., \& Schaffner, B. N. (2007). Winning coverage in the US Senate. Political communication, 24, 377-391.

Sevenans, J., Walgrave, S., \& Vos, D. (2015). Political elites' media responsiveness and their individual political goals: A study of national politicians in Belgium. Research \& Politics, 2(3), 2053168015593307.

Shaw, D. R. (1999). The Impact of News Media Favorability and Candidate Events in Presidential Campaigns. Political communication, 16(2), 183-202. doi: 10.1080/105846099198721

Shehata, A. (2010). Marking journalistic independence: Official dominance and the rule of product substitution in Swedish press coverage. European Journal of Communication, 25(2), 123-137.

Shehata, A., \& Strömbäck, J. (2014). Mediation of Political Realities: Media as Crucial Sources of Information. Mediatization of Politics: Understanding the Transformation of Western Democracies, 93.

Sigal, L. V. (1973). Reporters and Officials: The Organization and Politics of Newsmaking. Lexington, MA: D.C. Heath and Company.

Sjöblom, G. (1968). Party Strategies in a Multiparty System. Lund: Studentlitteratur.

Slothuus, R., \& De Vreese, C. H. (2010). Political parties, motivated reasoning, and issue framing effects. The Journal of Politics, 72(03), 630-645.

Soroka, S. N. (2002). Issue attributes and agenda-setting by media, the public, and policymakers in Canada. International Journal of Public Opinion Research, 14(3), 264-285.

Sparrow, B. H. (2006). A Research Agenda for an Institutional Media. Political communication, 23(2), 145-157. doi: 10.1080/10584600600629695

Strøm, K., Müller, W. C., \& Smith, D. M. (2010). Parliamentary control of coalition governments. Annual Review of Political Science, 13, 517-535.

Strömbäck, J. (2007). Political marketing and professionalized campaigning: A conceptual analysis. Journal of Political Marketing, 6(2-3), 49-67.

Strömbäck, J. (2008). Four Phases of Mediatization: An Analysis of the Mediatization of Politics. International Journal of Press Politics, 13(3), 228-246. 
Strömbäck, J., \& Esser, F. (2014). Mediatization of Politics: Towards a Theoretical Framework. In J. Strömbäck \& F. Esser (Eds.), Mediatization of Politics: Understanding the Transformation of Western Democracies (pp. 3-30). Basingstoke: Palgrave Macmillan.

Strömbäck, J., \& Van Aelst, P. (2013). Why Political Parties Adapt to the Media: Exploring the Fourth Dimension of Mediatization. International Communication Gazette, 75(4), 341-358.

Thesen, G. (2013). When good news is scarce and bad news is good: Government responsibilities and opposition possibilities in political agenda-setting. European Journal of Political Research, 52(3), 364-389. doi: 10.1111/j.1475-6765.2012.02075.x

Thesen, G. (2014). Political Agenda Setting as Mediatized Politics? Media-Politics Interactions from a Party and Issue Competition Perspective. The International Journal of Press/Politics, 19(2), 181-201. doi: 10.1177/1940161213515756

Tresch, A. (2009). Politicians in the media: Determinants of legislators' presence and prominence in Swiss newspapers. International Journal of Press/Politics, 14(1), 67-90. doi: $10.1177 / 1940161208323266$

van Dalen, A. (2011). Structural Bias in Cross-National Perspective: How Political Systems and Journalism Cultures Influence Government Dominance in the News. The International Journal of Press/Politics. doi: 10.1177/1940161211411087

Van Dalen, A., \& Van Aelst, P. (2014). The Media as Political Agenda-Setters: Journalists' Perceptions of Media Power in Eight West European Countries. West European Politics, 37(1), 42-64. doi: 10.1080/01402382.2013.814967

Van Noije, L., Oegema, D., \& Kleinnijenhuis, J. (2008). Loss of parliamentary control due to mediatization and europeanization: A longitudinal and cross-sectional analysis of agenda building in the United Kingdom and the Netherlands. British Journal of Political Science, 38(3), 455-478.

Van Santen, R., Van Aelst, P., \& Helfer, L. (2015). When politics becomes news: an analysis of parliamentary questions and press coverage in three West-European countries. Acta Politica, 50, 45-63. doi: 10.1057/ap.2013.33

Vliegenthart, R., \& Mena Montes, N. (2014). How Political and Media System Characteristics Moderate Interactions between Newspapers and Parliaments: Economic Crisis Attention in Spain and the Netherlands. The International Journal of Press/Politics, 19(3), 318-339. doi: $10.1177 / 1940161214531335$

Vliegenthart, R., \& Roggeband, C. (2007). Framing Immigration and Integration: Relationships between Press and Parliament in the Netherlands. International Communication Gazette, 69(3), 295-319. doi: 10.1177/1748048507076582

Vliegenthart, R., \& Walgrave, S. (2011a). Content matters. The Dynamics of Parliamentary Questioning in Belgium and Denmark. Comparative Political Studies, 44(8), 1031-1059.

Vliegenthart, R., \& Walgrave, S. (2011b). When the Media Matter for Politics: Partisan Moderators of Mass Media Influence on Parliament in Belgium, 1993-2000. Party Politics, 17(3), 321-342. doi: doi:10.1177/1354068810366016

Vos, D. (2014). Which politicians pass the news gates and why? Explaining inconsistencies in research on news coverage of individual politicians. International Journal of Communication, 8, 24382461.

Waismel-Manor, I., \& Tsfati, Y. (2011). Why Do Better-Looking Members of Congress Receive More Television Coverage? Political communication, 28(4), 440-463. doi: 10.1080/10584609.2011.617719

Walgrave, S., Soroka, S., \& Nuytemans, M. (2008). The mass media's political agenda-setting power. A longitudinal analysis of media, parliament and government in Belgium (1993-2000) Comparative Political Studies, 41(6), 814-836.

Wolfe, M., Jones, B. D., \& Baumgartner, F. R. (2013). A Failure to Communicate: Agenda Setting in Media and Policy Studies. Political communication, 30(2), 175-192. doi: 10.1080/10584609.2012.737419 
Information and Arena. 31

Wolfsfeld, G. (2011). Making sense of Media \& Politics. Five principles of political communication. New York: Routledge.

Wolfsfeld, G., \& Sheafer, T. (2006). Competing actors and the construction of political news: the contest over waves in Israel. Political communication, 23, 333-354.

Yanovitsky, I. (2002). Effects of news coverage on policy attention and actions: A closer look into the media-policy connection. Communication Research, 29, 422-451. 